\title{
Abnormal Urinalysis Results Caused by Interfering Substances
}

Wonmok Lee ${ }^{1}$, Yukyung $\mathrm{Kim}^{2}$, Soonhee Chang ${ }^{3}$, A-Jin Lee, ${ }^{4}$ and ChangHo Jeon ${ }^{4}$

${ }^{1}$ Department of Laboratory

Medicine, Keimyung

University School of

Medicine; ${ }^{2}$ Department of Laboratory Medicine,

Yeungnam University

College of Medicine;

${ }^{3}$ Department of Laboratory

Medicine, Daegu Fatima

Hospital; ${ }^{4}$ Department

of Laboratory Medicine,

Catholic University of

Daegu School of Medicine,

Daegu, Korea

Corresponding author:

Chang-Ho Jeon

Department of Laboratory

Medicine, Catholic University of

Daegu School of Medicine, 33

Duryugongwon-ro 17-gil, Nam-

gu, Daegu 42472, Korea

Tel: +82-53-650-4144

Fax: +82-53-653-8672

E-mail: chjeon@cu.ac.kr
Background: To understand causes of abnormal reaction for the urinalysis, we analyze the interfering substances of clinical urine samples. We focused the effect of urinary vitamin C and fluorescein sodium to the urine chemistry especially glucose, hemoglobin, and leukocyte esterase.

Methods: Incidence of urinary vitamin $\mathrm{C}$ was determined for patients and people underwent a medical check-up. We decided dipstick results of glucose, hemoglobin, and leukocyte esterase as false negative based on urine sediment and serum glucose results. Dipstick urinalysis was tested by URiSCAN Pro III with URiSCAN 11 strip (YD Diagnostics, Korea). Urine sediments tests were performed by manual microscopic analysis or Sysmex UF-1000i (Sysmex Co., Japan).

Results: The incidence of vitamin C was $20.4 \%$ for all subjects. The positive rate of the medical check-up group $(34.6 \%)$ was higher than others. When vitamin $\mathrm{C}$ was detected in clinical urine samples, $42.3 \%, 10.6 \%$, and $8.2 \%$ were defined as false negative for glucose, hemoglobin, and leukocyte esterase dipstick tests, respectively. Fluorescein sodium also interfered on the results of hemoglobin and leukocyte esterase of the dipstick reagents.

Conclusions: Vitamin C was frequently found in the clinical urine samples, and its incidence was higher in the people who underwent medical check-up. The urinary vitamin $\mathrm{C}$ and fluorescein sodium can cause interferences in urine dipstick results. Thus, it is expected that present study will give useful information to predict false negative rates of urine dipstick tests by vitamin $\mathrm{C}$ and fluorescein sodium.

(J Lab Med Qual Assur 2017;39:76-82)

Key Words: Ascorbic acid, Fluorescein, Urinalysis, Interference

Received October 17, 2016, Revision received December 6, 2016, Accepted December 8, 2016

\section{서론}

요검사는 검체 채취와 검사방법이 용이하면서도 여러 질 환의 진단, 치료 및 예후 결정에 필수적인 정보를 제공하는 중요한 선별검사 중 하나이다 $[1,2]$. 그 중 요시험지(urine dipstick)를 이용한 화학적 검사는 한번의 검사로 소변 내의 $\mathrm{pH}$, 요당, 단백, 빌리루빈, 케톤, 잠혈, 우로빌리노겐, 아질산 염, 백혈구 및 비중에 대한 총 10 가지 항목을 측정하여 당뇨, 신장질환, 간질환 및 요로계 감염 등의 진단 및 추적에 이용되 고 있다.
요화학검사에 영향을 미치는 다양한 간섭물질들이 밝혀져 있다. 그 중 비타민 $\mathrm{C}$ 는 요당, 잠혈, 백혈구 및 아질산염 반응 에 영향을 주어 흔히 위음성의 결과를 유발한다[3]. 또한 안구 검사를 위해 사용되는 안과 조영제(fluorescein sodium) 역시 요시험지검사에 영향을 주는 것으로 알려져 있다[4]. 하지만 아직까지 국내에서는 요검사 대상자의 요중 비타민 $\mathrm{C}$ 의 양성 빈도나 안과 조영제에 의한 간섭영향 등에 대한 연구조사가 이 루어 진 바가 없다.

이에 본 저자는 최근 소개된 비타민 C 농도를 동시에 측정할 수 있는 요시험지를 이용하여 요검사 대상자의 요중 비타민 C 
양성률을 조사하고 실제 비타민 C 및 안과 조영제가 병원에서 시행되는 요화학검사 중 요당, 잠혈, 백혈구 결과에 어느 정도 의 간섭을 미치는지 조사하여 분석하고자 하였다.

\section{재료 및 방법}

\section{1. 재료}

2015년 7월 27일부터 11월 31일까지 대구지역 4개 병원 진 단검사의학과로 요화학검사와 요침사검사가 의뢰된 임의뇨 (random spot urine) 잔여 검체를 대상으로 하였다. 모든 검 체는 각 기관 검사실로 접수된 시간을 참고하여 아침 첫 소변 으로 판단되는 검체만을 선택하였다. 본 연구는 각 기관의 임 상시험심사위원회(institutional review board, IRB)의 승인 을 얻어 시행되었다(IRB no., 2015-05-041, CR-15-057-L).

\section{2. 요화학검사}

요화학검사는 자동 요분석기인 URiSCAN Pro III (YD Diagnostics, Yongin, Korea) 장비에 전용 요시험지 URiSCAN 11 strip (YD Diagnostics)을 이용하여 요당, 잠 혈, 백혈구 및 비타민 $\mathrm{C}$ 를 측정하였다. 모든 요검사는 각 기관 에서 정규검사를 위해 사용하고 있는 방법으로 검사를 시행한 후 즉시 이루어졌다. 항목별 검사결과는 Table 1에 명시된 등 급에 따라 보고되었고 모두 동일한 제조번호의 요시험지를 사 용하여 평가를 진행하였다.

\section{3. 요침사검사}

두 기관은 수기법으로, 나머지 두 기관에서는 자동 요침사 분석장비인 Sysmex UF-1000i (Sysmex Co., Kobe, Japan) 로 측정한 요침사 결과를 사용하였다. 수기법은 소변을 20배 농축한 침사를 광학현미경으로 관찰한 다음 '수/high power field (HPF)' 단위로 측정하였다. UF-1000i에의 얻어진 '수/ $\mu \mathrm{L}^{\prime}$ 단위의 요침사 결과와 두 기관에서 얻어진 수기법 요침사 결과는 Clinical and Laboratory Standards Institute 기준 GP16-A3에 따라 사용된 $\mathrm{HPF}$ 직경, 커버슬립 면적, 요침사 농축배율, 침사의 양 등을 고려해 표준화된 ‘수/ $\mathrm{HPF}$ ' 단위로 변환시켰다[5]. 요침사 결과는 Table 2에 명시된 등급에 따라 분류한 결과를 사용하였다.

\section{4. 혈당}

요검사용 검체와 동일한 시간대에 접수된 혈액 검체를 대상 으로 각 기관에서 사용 중인 자동생화학분석기와 전용 시약 을 이용하여 혈청 내의 혈당을 측정하였다. 사용된 분석기는 ADVIA 2400 (Siemens Healthcare Diagnostics, Erlangen, Germany), AU5800 (Beckman Coulter, Brea, CA, USA), COBAS c702 (Roche Diagnostics, Basel, Switzerland), 및 Modular DP (Roche Diagnostics, Mannheim, Germany)이다.

\section{5. 요중 비타민 C 양성 빈도}

요중 비타민 $\mathrm{C}$ 양성 빈도는 연구기간 내 1 개월 동안 URiSCAN 11 strip을 정규검사로 사용하고 있는 2개 기관으 로 의뢰된 모든 외래, 입원환자 및 건강검진 대상자의 요검사 결과 자료를 각각 분석하여 계산하였다.

\section{6. 비타민 C 유무에 따른 요시험지 간섭}

4개 병원 진단검사의학과 검사실로 요검사가 의뢰된 입원 환자의 요중 비타민 C가 양성인 1,509예를 대상으로 하였 다. 요화학검사의 잠혈, 백혈구와 요침사검사의 적혈구, 백혈 구 결과와의 상관성을 확인하기 위해서 Spearman 상관분석 을 시행하였다. 통계적 분석을 위해서 Microsoft Excel 2016 (Microsoft, Redmond, WA, USA)과 Analyze-it ver. 4.06.1

Table 1. Grading system of URiSCAN 11 strip

\begin{tabular}{|c|c|c|c|c|c|}
\hline Parameters & & & Grad & & \\
\hline Glucose (negative) & Trace & $1+$ & $2+$ & $3+$ & $4+$ \\
\hline Red blood cell (negative) & Trace & $1+$ & $2+$ & $3+$ & \\
\hline White blood cell (negative) & Trace & $1+$ & $2+$ & $3+$ & \\
\hline Vitamin C (negative) & $1+$ & $2+$ & $3+$ & & \\
\hline
\end{tabular}

Table 2. Grading systems used in the analysis of urine particles

\begin{tabular}{cccccc}
\hline Parameters & \multicolumn{3}{c}{ Grade } \\
\hline Red blood cell, white blood cell (counts/HPF) & $<1$ & $1-4$ & $5-9$ & $10-29$ & $\geq 30$ \\
\hline Abbreviation: HPF, high power field.
\end{tabular}

Abbreviation: HPF, high power field.

www.jlmqa.org J Lab Med Qual Assur 2017;39:76-82 
Wonmok Lee et al • Abnormal Urinalysis Results

(Analyze-it Software, Leeds, UK)을 이용하였다. 요화학검 사와 동시에 시행된 요침사검사와 혈당검사 결과를 기준으로 각 항목별 다음의 경우를 위음성으로 판정하였다. (1) 요당: 혈당 $180 \mathrm{mg} / \mathrm{dL}$ 이상 시 요당이 음성인 경우, (2) 잠혈, 백혈 구: 요화학검사 결과가 요침사검사 결과보다 두 등급 이상 낮 은 경우.

\section{7. 안과 조영제 유무에 따른 요시험지 간섭}

요검사가 의뢰된 소변 검체 중 형광 빛을 보이는 경우 환자 의 의무기록을 조사하여 조영제 사용 여부를 확인하였다. 조영 제를 사용한 환자의 요화학검사 결과를 동일 검체로 시행한 요 침사검사 결과 및 동시에 시행된 혈당검사 결과와 비교하여 간 섭 유무를 판정하였다.

\section{결과}

\section{1. 요중 비타민 C 양성 빈도}

총 7,225 예의 소변에서 비타민 $\mathrm{C}$ 가 양성인 예는 1,471 예로
$20.4 \%$ 의 비율을 보였다. Table 3에 제시한 바와 같이 외래환 자, 입원환자, 건강검진대상자 군에서 다소의 차이를 보였다.

\section{2. 비타민 C 양성에 따른 요시험지 간섭}

소변에서 비타민 $\mathrm{C}$ 가 검출되면서 혈당이 $180 \mathrm{mg} / \mathrm{dL}$ 를 초 과하는 경우는 총 175예였다. 그 중 74예(42.3\%)는 요화학검 사 중 요당검사에서 위음성의 결과를 보였다(Table 4).

요중 비타민 $\mathrm{C}$ 가 양성일 때, 요화학검사의 잠혈, 백혈구와 요침사검사의 적혈구, 백혈구 사이의 상관계수는 각각 0.684 및 0.661였다(Tables 5, 6), 요중 비타민 C가 양성일 때, 잠혈 결과는 요침사 적혈구 결과와 1,323예(87.7\%)에서 한 등급 차 이내의 일치율을 보였고(Table 5), 백혈구 결과는 요침사 백혈 구 결과와 1,368예(90.8\%)에서 한 등급 차이 이내의 일치율을 보였다(Table 6). 하지만 요화학검사 잠혈과 백혈구 중 각 160 예(10.6\%)와 124예(8.2\%)는 위음성의 결과를 보였다.

\section{3. 안과 조영제 유무에 따른 요시험지 간섭}

연구기간 동안 총 9 개의 형광 빛을 띠는 소변이 검사실로 접

Table 3. Incidence of positive dipstick test results for vitamin C

\begin{tabular}{llll}
\hline Classification & Hospital A & Hospital B & Total \\
\hline In-patient & $13.2(218 / 1,654)$ & $19.7(203 / 1,032)$ & $15.7(421 / 2,686)$ \\
Out-patient & $16.2(40 / 247)$ & $20.2(667 / 3,300)$ & $19.9(707 / 3,507)$ \\
Medical check-up & $35.0(113 / 323)$ & $34.4(230 / 669)$ & $34.6(343 / 992)$ \\
Total & $16.7(371 / 2,224)$ & $22.0(1,100 / 5,500)$ & $20.4(1,471 / 7,225)$ \\
\hline
\end{tabular}

Values are presented as \% (number/total number).

Table 4. Interference of urine dipstick glucose results by vitamin $\mathrm{C}$

\begin{tabular}{ccccccccc}
\hline & \multicolumn{7}{c}{ Urine glucose (\%) } \\
\cline { 2 - 8 } & - & Trace & $1+$ & $2+$ & $3+$ & $4+$ & Total \\
\hline Vitamin C + & $74(42.3)$ & $18(10.3)$ & $10(5.7)$ & $17(9.7)$ & $45(25.7)$ & $11(6.3)$ & $175^{*}$ \\
\hline
\end{tabular}

*Serum glucose levels were above $180 \mathrm{mg} / \mathrm{dL}$ for all cases.

Table 5. Comparison of the pairwise results for RBC in urine dipstick and sediment tests

\begin{tabular}{|c|c|c|c|c|c|c|c|c|}
\hline & \multirow{2}{*}{ RBC-dipstick } & \multicolumn{6}{|c|}{ RBC-sediment (counts/HPF) } & \multirow{2}{*}{$r$} \\
\hline & & $<1$ & $1-4$ & $5-9$ & $10-29$ & $\geq 30$ & Sum & \\
\hline \multirow[t]{5}{*}{ Vitamin C + } & Negative & $691^{\star}$ & $255^{\dagger}$ & 91 & 20 & 7 & 1,064 & $0.684^{\ddagger}$ \\
\hline & Trace & $24^{\dagger}$ & $51^{\star}$ & $53^{\dagger}$ & 15 & 9 & 152 & \\
\hline & $1+$ & 3 & $21^{\dagger}$ & $42^{*}$ & $23^{\dagger}$ & 18 & 107 & \\
\hline & $2+$ & 2 & 14 & $18^{\dagger}$ & $23^{*}$ & $16^{\dagger}$ & 73 & \\
\hline & $3+$ & 0 & 3 & 4 & $14^{\dagger}$ & $92^{*}$ & 113 & \\
\hline
\end{tabular}

Abbreviations: RBC, red blood cell; HPF, high power field; $r$, Spearman's correlation coefficient.

${ }^{\star}$ No. with the same grade. ${ }^{\dagger}$ No. of cases within one grade difference. ${ }^{\ddagger} P<0.05$. 
Journal of LABORATORY MEDICINE and QUALITY ASSURANCE

Wonmok Lee et al • Abnormal Urinalysis Results

Table 6. Comparison of the pairwise results for WBC in urine dipstick reagent and sediment analysis

\begin{tabular}{|c|c|c|c|c|c|c|c|c|}
\hline & \multirow{2}{*}{ WBC-dipstick } & \multicolumn{6}{|c|}{ WBC-sediment (counts/HPF) } & \multirow{2}{*}{$\boldsymbol{r}$} \\
\hline & & $<1$ & $1-4$ & $5-9$ & $10-29$ & $\geq 30$ & Sum & \\
\hline \multirow[t]{5}{*}{ Vitamin C + } & Negative & $696^{*}$ & $264^{\dagger}$ & 55 & 26 & 10 & 1,051 & $0.661^{*}$ \\
\hline & Trace & $41^{\dagger}$ & $70^{*}$ & $39^{\dagger}$ & 14 & 3 & 167 & \\
\hline & $1+$ & 4 & $33^{\dagger}$ & $41^{\star}$ & $35^{\dagger}$ & 16 & 129 & \\
\hline & $2+$ & 1 & 7 & $10^{\dagger}$ & $30^{*}$ & $41^{\dagger}$ & 89 & \\
\hline & $3+$ & 0 & 3 & 0 & $16^{\dagger}$ & $52^{*}$ & 71 & \\
\hline
\end{tabular}

Abbreviations: WBC, white blood cell; HPF, high power field; $r$, Spearman's correlation coefficient.

${ }^{\star}$ No. with the same grade. ${ }^{\dagger}$ No. of cases within one grade difference. ${ }^{\ddagger} P<0.05$.

Table 7. Interference of urine dipstick results by sodium fluorescein

\begin{tabular}{|c|c|c|c|c|c|c|}
\hline \multirow[b]{2}{*}{ No. of case } & \multicolumn{2}{|c|}{ Glucose } & \multicolumn{2}{|c|}{ Red blood cell } & \multicolumn{2}{|c|}{ White blood cell } \\
\hline & Blood $(\mathrm{mg} / \mathrm{dL})$ & Urine & $\begin{array}{c}\text { Sediment } \\
\text { (counts/HPF) }\end{array}$ & Dipstick & $\begin{array}{c}\text { Sediment } \\
\text { (counts/HPF) }\end{array}$ & Dipstick \\
\hline 1 & 87 & Negative & $10-29$ & $1+$ & $<1$ & Negative \\
\hline 2 & 111 & Negative & $<1$ & Negative & $10-29$ & Negative $^{*}$ \\
\hline 3 & 112 & $1+$ & $5-9$ & Negative $^{*}$ & $10-29$ & Negative $^{*}$ \\
\hline 4 & 144 & Negative & $5-9$ & Negative $^{*}$ & $\geq 30$ & Negative $^{\star}$ \\
\hline 5 & 191 & Negative $^{*}$ & $1-4$ & Negative & $<1$ & Negative \\
\hline 6 & Not tested & Negative & $10-29$ & Negative $^{*}$ & $\geq 30$ & Negative $^{*}$ \\
\hline 7 & 265 & $4+$ & $5-9$ & Negative $^{*}$ & $5-9$ & Negative $^{*}$ \\
\hline 8 & 310 & $3+$ & $<1$ & Negative & $<1$ & Negative \\
\hline 9 & 500 & $4+$ & $<1$ & Negative & $1-4$ & Negative \\
\hline
\end{tabular}

Abbreviation: HPF, high power field.

${ }^{\star}$ These urine dipstick results were rated as false negatives based on the urine sediment and blood glucose results.

수되었고 모두 안과 조영제를 사용한 것으로 확인되었다. 이들 검체에서는 모두 비타민 $\mathrm{C}$ 가 검출되지 않았으며, 조영제에 의 한 요화학검사의 간섭현상은 Table 7에 요약하였다. 안과 조 영제가 함유된 요 검체와 요시험지에 대한 색상간섭은 Fig. 1 에 제시하였다.

\section{고찰}

비타민 $\mathrm{C}$ 는 가장 흔하게 사용되는 건강보조제 중 하나이지 만 요화학검사 결과에 간섭을 미치는 물질로도 잘 알려져 있 다. 1992년 미국 서부 해안지역 인구를 대상으로 시행한 연구 에 따르면 해당 지역 인구의 $22.8 \%$ 에서 URiSCAN 11 strip 의 비타민 C 검출한계 $(10 \mathrm{mg} / \mathrm{dL})$ 와 동일한 비타민 C 요시험 지에서 요중 비타민 $\mathrm{C}$ 가 검출되었다[6]. 본 연구에서는 국내 대구 지역 요검사 대상자를 대상으로 비타민 C 양성률를 확인 하였고 그 결과 $20.4 \%$ 로 유사한 양성률을 보이는 것을 확인하

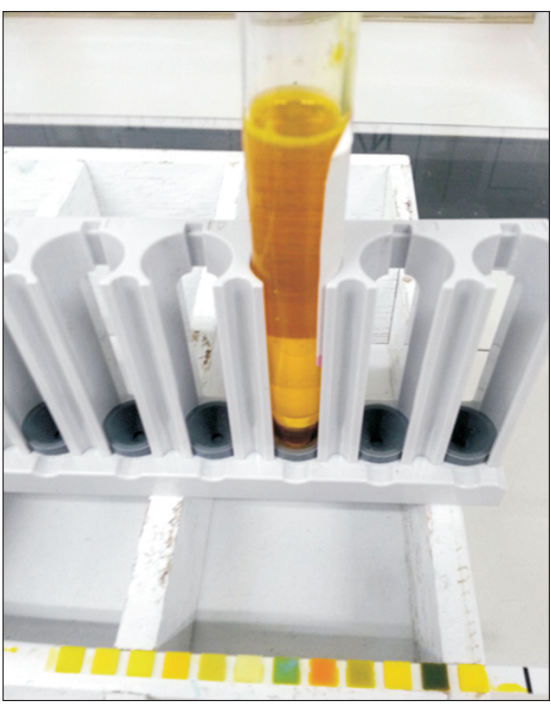

Fig. 1. A urine specimen containing fluorescein sodium and its interference on the urine dipstick. 
였다. 하지만 흥미로운 점은 두 기관 모두 입원, 외래 환자군보 다 건강검진대상자 군에서 양성률이 유의하게 높은 결과를 보 였다는 것이다. 이러한 현상은 환자군에 비해 건강검진대상자 군이 건강에 대한 관심이 높아서 비타민 $\mathrm{C}$ 등의 건강보조제를 더 많이 섭취하기 때문에 관찰된 것으로 유추할 수 있다. 따라 서 전체 요화학검사 대상자 중 약 $20 \%$ 는 위음성의 결과를 보 일 가능성이 있고, 특히 건강검진대상자 군은 환자군에 비해 비타민 C에 의한 간섭을 받을 확률이 더 높을 것으로 예측된 다. 요화학검사는 다양한 질환의 선별검사이기에 한번의 검사 로 요화학검사 결과와 요중 비타민 $\mathrm{C}$ 의 존재 여부를 확인할 수 있다면 결과의 위음성 예측에 도움을 줄 수 있을 것으로 기대 된다.

요당은 고혈당 이외의 다른 신질환에서도 관찰될 수 있지만, 일반적으로 혈당이 $180 \mathrm{mg} / \mathrm{dL}$ 를 초과하는 경우 검출된다[2]. 소변 내 당의 정량검사는 일반적으로 시행되지 않기에 저자들 은 혈당이 $180 \mathrm{mg} / \mathrm{dL}$ 를 초과할 시 요화학검사에서 요당이 검 출되지 않을 경우를 위음성으로 간주하였다. 이 연구에서는 혈 당이 $180 \mathrm{mg} / \mathrm{dL}$ 를 초과하는 총 175 예 중 $42.3 \%$ 가 위음성으 로 확인되었다.

현재까지 상용화되어 있는 다양한 자동 요침사 분석기는 주 요 항목들에 대해 정량적 수치보고가 가능하지만, 여전히 요 침사 결과는 반정량적인 등급체계가 가장 널리 사용되고 있다 $\lceil 7,8]$. 저자들은 대한진단검사의학회에서 제시한 기준을 일부 수정한 등급체계에 따라 분류한 적혈구와 백혈구 요침사 결과 를 요화학검사 결과의 위음성 여부를 예측하기 위해 잠혈, 백 혈구의 결과와 직접 비교하였다[1].

요중 비타민 $\mathrm{C}$ 가 검출되었을 때, 잠혈과 백혈구에 대한 두 검사방법 사이의 Spearman 상관계수는 각각 0.684 및 0.661 으로 이전 보고에서 비타민 C 여부를 확인하지 않은 소변 검체 를 대상으로 시행한 분석보다 낮은 상관성을 보이는 것으로 확 인되었다(잠혈, $r=0.865$; 백혈구, $r=0.764$ ) [8]. 잠혈과 백혈 구에 대한 두 방법 간의 일치율은 각각 $87.7 \%$ 및 $90.8 \%$ 로 우 수하였다. 하지만 잠혈과 백혈구에 대한 요화학검사의 $10.6 \%$ 및 $8.2 \%$ 는 위음성으로 확인되었으며, 특히 요침사 결과가 5/ $\mathrm{HPF}$ 를 초과하는 경우에는 잠혈검사의 $26.5 \%$ (118/445), 백 혈구검사의 $23.5 \%$ (91/338)가 음성의 결과를 보였다. 따라서 비타민 C를 섭취한 사람들을 대상으로 선별검사의 목적으로 요화학검사만 시행하게 된다면 이상 잠혈 혹은 백혈구를 가지 고 있는 사람의 약 $1 / 4$ 은 선별되지 않을 수 있다. 따라서 선별 검사로서 요화학검사의 진단성능을 향상시키기 위해 요중 비 타민 C 검사 혹은 요침사검사를 동시에 시행하는 것이 유용할 것으로 생각된다.
실제 안과 조영제가 포함된 검체가 검사실로 접수된 예는 많 지 않았고, 연구기간 동안 임상으로 이상결과에 대한 피드백 으로 검체가 줄어 많은 수의 예를 확보할 수는 없었지만 이전 보고에서와 같이 요화학검사에 간섭을 주는 것을 확인하였다 [4]. 특히 요침사에서 $5 / \mathrm{HPF}$ 를 초과하는 경우 잠혈 1 예를 제 외하고는 모든 잠혈, 백혈구의 요화학검사 결과가 요화학분석 장비에서 음성으로 보고되었다. 뿐만 아니라 육안으로도 분석 이 어려울 정도의 색 간섭을 보여 안과 조영제가 포함된 요 검 체로는 정확한 결과를 판정하기가 불가능할 것으로 생각되었 다.

현재까지 국내에서는 비타민 C에 의한 요화학검사에 간섭 에 실험실적 연구는 있어 왔으나 실제 요중 비타민 $\mathrm{C}$ 양성률 및 대량의 환자 검체를 이용한 분석은 이루어진 바가 없었다 [9]. 이번 연구는 비타민 C에 의한 간섭을 직접 확인하기 위한 요중 비타민 $\mathrm{C}$ 음성인 검체와의 비교연구 및 요중 비타민 $\mathrm{C}$ 의 농도에 따른 분석이 이루어지지 못한 점, 또한 요침사와 요화 학검사 간의 동일한 등급체계를 사용하지 못한 점 등의 제한점 을 가진다. 하지만 본 연구는 국내에서 처음으로 임상 검체를 이용하여 비타민 $\mathrm{C}$ 의 양성률과 간섭현상을 규명하였으며, 임 상 검체에서 발생하는 위음성 빈도를 확인하였다. 또한 안과 조영제에 의한 간섭현상도 확인하여 향후 각 기관에서 보다 정 확한 요화학검사를 시행하는 데 유용한 자료로 활용될 수 있을 것으로 기대된다.

\section{감사의 글}

본 연구는 대한임상검사정도관리협회의 연구비 지원으로 수 행되었다(2015).

\section{REFERENCES}

1. Korean Society of Laboratory Medicine. Laboratory medicine. 5th ed. Seoul: Panmun Education, 2014:497-508.

2. McPherson RA, Ben-Ezra J. Basic examination of urine. In: McPherson RA, Pincus MR, editors. Henry's clinical diagnosis and management by laboratory methods. 22nd ed. Philadelphia (PA): Saunders, 2011:445-79.

3. Simerville JA, Maxted WC, Pahira JJ. Urinalysis: a comprehensive review. Am Fam Physician 2005;71:1153-62.

4. Henemyre-Harris CL, Samols M, Wenick AS, Sokoll LJ. Glow stick or urine sample? Clin Chem 2014;60:425-6.

5. Clinical and Laboratory Standards Institute. Urinalysis: 


\section{Journal of LABORATORY MEDICINE and QUALITY ASSURANCE}

Wonmok Lee et al • Abnormal Urinalysis Results

approved guideline. 3rd ed. Wayne (PA): Clinical and Laboratory Standards Institute, 2010.

6. Brigden ML, Edgell D, McPherson M, Leadbeater A, Hoag G. High incidence of significant urinary ascorbic acid concentrations in a west coast population: implications for routine urinalysis. Clin Chem 1992;38:426-31.

7. Manoni F, Tinello A, Fornasiero L, Hoffer P, Temporin V, Valverde S, et al. Urine particle evaluation: a comparison between the UF-1000i and quantitative microscopy. Clin
Chem Lab Med 2010;48:1107-11.

8. Yuksel H, Kilic E, Ekinci A, Evliyaoglu O. Comparison of fully automated urine sediment analyzers H800-FUS100 and LabUMat-UriSed with manual microscopy. J Clin Lab Anal 2013;27:312-6.

9. Ko DH, Jeong TD, Kim S, Chung HJ, Lee W, Chun S, et al. Influence of vitamin $\mathrm{C}$ on urine dipstick test results. Ann Clin Lab Sci 2015;45:391-5. 
간섭물질들에 의한 요화학검사의 이상결과 반응 이원목 ${ }^{1}$ - 김유경 ${ }^{2}$ - 장순희 $\left.\right|^{3}$ - 이아진 ${ }^{4}$ - 전창호 ${ }^{4}$

${ }^{1}$ 계명대학교 의과대학 진단검사의학과, ${ }^{2}$ 영남대학교 의과대학 진단검사의학과, ${ }^{3}$ 대구파티마병원 진단검사 의학과, ${ }^{4}$ 대구가톨릭대학교 의과대학 진단검사의학과

배경: 비타민 C는 요화학검사에 간섭을 미치는 물질로 알려져 있으며, 안과 조영제(fluorescein sodium)는 소변으로 배설되어 형광 빛을 띈다. 본 연구는 요검사 대상자의 요중 비타민 C 양성률과 비타민 C 및 안과 조영제가 요화학검사 중 요당, 잠혈, 백혈구 결과에 미치는 간섭 정도를 조사하였 다.

방법: 입원, 외래환자 및 검강검진대상자를 구분하여 요중 비타민 C 양성률를 조사하였다. 요화학검 사 중 요당, 잠혈, 및 백혈구의 결과를 혈당과 요침사 결과를 기준으로 하여 위음성을 판정하였다. 요 화학검사는 URiSCAN pro III (YD Diagnostics, Korea) 장비에 전용 요시험지 URiSCAN 11 strip (YD Diagnostics)을 이용하여 당, 잠혈, 백혈구 및 비타민 C를 측정하였다. 요침사검사는 수기법 혹 은 Sysmex UF-1000i (Sysmex Co., Japan)로 시행하였다.

결과: 모든 군에 대해서 요중 비타민 C 양성률은 $20.4 \%$ 였으나, 건강검진대상자 군(34.6\%)에서 환 자군보다 높은 양성률을 보였다. 요중 비타민 C가 검출되었을 때, 요화학검사 중 요당, 잠혈, 및 백혈 구 결과의 $42.3 \%, 10.6 \%$ 및 $8.2 \%$ 가 위음성으로 확인되었다. 안과 조영제 역시 요화학검사 중 잠혈 과 백혈구 결과에 간섭을 주었다.

결론: 비타민 $\mathrm{C}$ 는 임상 소변 검체에서 흔히 검출되며 그 빈도는 건강검진대상자 군에서 더 높다. 요중 비타민 C와 안과 조영제는 요화학검사에 간섭현상을 유발시킬 수 있다. 따라서 이 연구는 비타민 C와 안과 조영제에 의한 요화학검사에 대한 위음성률을 예측하는 데 유용한 자료로 활용될 수 있을 것으 로 기대된다.

(J Lab Med Qual Assur 2017;39:76-82) 